\title{
Результати досліджень роботи дослідного зразка спеціалізованої сівалки для сумісних посівів кормових культур
}

\author{
В.І. Мельник ${ }^{1}$, В.І. Пастухов ${ }^{2}$, М.В. Бакум, М.О. Циганенко ${ }^{3}$, \\ С.М. Скофенко, О.А. Романашенко ${ }^{4}$, В.В. Качанов, Д.В. Крохмаль \\ Харківський національний університет сільського господарства \\ імені Петра Василенка (м. Харків, Україна) \\ email:1 victor_melnik@ukr.net, 2 pastukhov.v@ukr.net, ${ }^{3}$ cmixail@ukr.net \\ ORCID: ${ }^{1}$ 0000-0002-1176-2831 ${ }^{2}$ 0000-0002-5599-1548, ${ }^{4}$ 0000-0002-0857-6288
}

\begin{abstract}
В статті наведені результати досліджень в 2017 та 2018 роках роботи дослідного зразка спеціальної сівалки на базі «Vega-8 Profi» для сумісних посівів зернових та бобових кормових культур. Дослідження проводились в виробничих умовах двох дослідних господарств - інституту Північного Сходу національної академії аграрних наук України в Харківський (2017 рік) та Сумській (2018 рік) областях.

При дослідженнях, які проводились відповідно до розробленої програми та методики, визначались показники якості роботи сівалки, вплив сумісного посіву кукурудзи та сої на врожайність силосної маси, а також вплив отриманої силосної маси на продуктивність корів.

Цінність сумісних посівів полягає в ефективному використанні земельних площ, а також більш якісному складу кормів. Найбільш ефективними є сумісні посіви кормових культур з бобовими, які не тільки збагачують ґрунт азотом, що утворюється на коренях бобових, а і збільшують кількість білка та протеїну в кормовій одиниці. Крім визначення переваг та позитивних сторін в роботі дослідного зразка сівалки, фріксувалися відмови та недоліки в роботі сівалки, які стали підставою для подальшого удосконалення її конструкції.

Узагальнюючи результати дворічних досліджень роботи сівалки показали, що сумісні посіви кукурудзи та сої забезпечують урожайність силосної маси на $30 \%$ вище, ніж при посівах тільки кукурудзи. Відповідно до програми досліджень, у 2018 році вивчався вплив силосної маси сумісних посівів на продуктивність корів. Методом господарського обліку визначались надої молока та його якість за умови, що в раціоні корів був силос сумісних посівів кукурудзи та сої, а також приріст ваги при відгодівлі телиць силосом з сумісних посівів.

Годівля корів отриманим силосом забезпечила підвищення удою та жирності молока та приріст ваги при відгодівлі телиць в порівнянні з силосом тільки кукурудзи.
\end{abstract}

Ключові слова: дослідний зразок, сівалка, сумісні посіви, кормові культури, якість сівби, біологічна врожайність, силосна маса, ефективність кормів, продуктивність корів.

Стан питання. Як відомо, розвиток тваринництва, його продуктивність та ефективність в значній мірі залежать від забезпеченості різноманітними та повноцінними кормами, здатними забезпечувати всі потреби тварин. Серед різноманітних технологій виробництва кормових культур важливе місце займають сумісні посіви, тобто такі, при яких на одному полі розміщується одночасно декілька кормових культур [1]. Цінність сумісних посівів полягає в ефективному використанні земельних площ, а також більш якісному складу кормів. Найбільш ефективними $€$ сумісні посіви кормових культур з бобовими, які не тільки збагачують ґрунт азотом, що утворюється на коренях бобових, а і збільшують кількість білка та протеїну в кормовій одиниці.

Як свідчать численні дослідження в Україні, найбільш ефективними є сумісні посіви кукурудзи та сої в тому випадку, якщо їх насіння висівається в однин рядок [1-6]. Так як до теперішнього часу була відсутня в Україні сівалка, яка б здійснювала таку технологічну операцію, то застосовувались менш ефективні способи сумісних посівів: наприклад, сівба через рядок. 
Внаслідок плідної співпраці науковців ХНТУСГ та спеціалістів ПАО «Ельворті» в короткі строки була розроблена та виготовлена спеціалізована сівалка на базі «Vega-8 Profi» для сумісної сівби просапних культур, яка дозволяє висівати насіння двох культур в один рядок [2].

Враховуючи новизну конструкції і новизну технології сумісних посівів, були проведені дослідження роботи зразка сівалки в господарчих умовах двох державних дослідних господарствах інституту Північного сходу Національної академії аграрних наук України (табл. 1). Дослідження проводились в 2017 та 2018 роках відповідно до розробленої програми та методики, які передбачали визначення показників якості роботи сівалки, вплив сумісного посіву кукурудзи і сої на врожайність силосної маси, а також вплив отриманої силосної маси на продуктивність корів.

Таблиця 1. Місця проведення досліджень спеціалізованої сівалки для сумісних посівів кормових культур

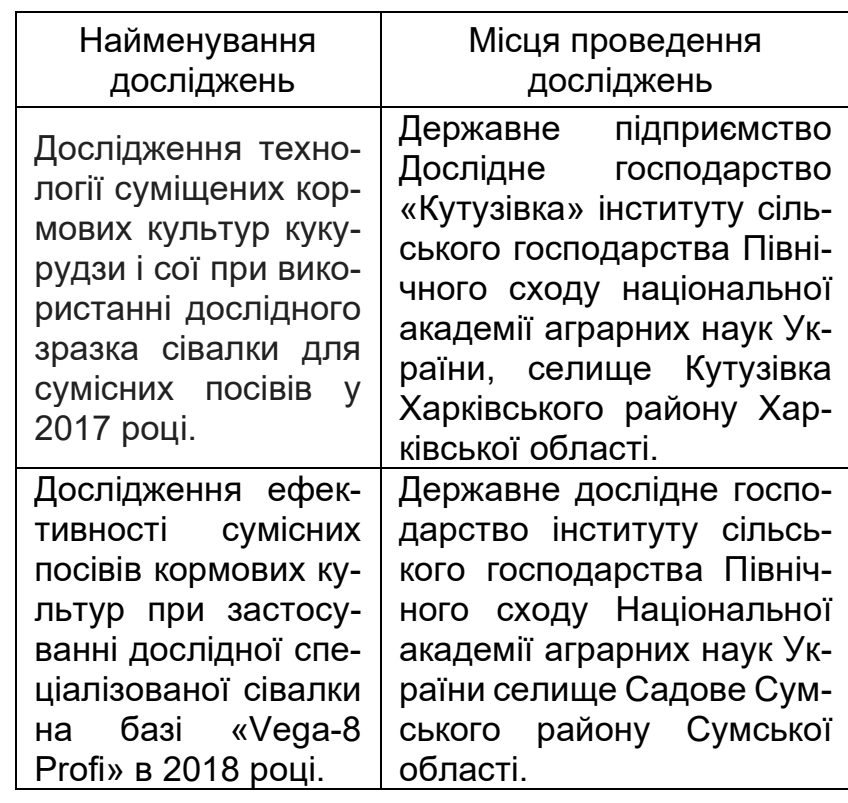

Необхідність продовження досліджень в 2018 році диктувалася, з одного боку, новизною конструкції та технології сумісних посівів, а також погодними умовами 2017 року (значна посуха), що не дозволило повністю визначити як переваги сівалки, так і ефективність сумісних посівів.

Культури та їх сорти, що висівались при дослідженнях, представлені в табл. 2. Як свідчить аналіз даних таблиці, насіння кукурудзи і сорго відзначались високою (98\%) лабораторною схожістю, що могло б забезпечувати і досить високу польову схожість.

Агрегатування сівалки в 2017 році відбувалось з трактором ХТЗ-242К (рис. 1), а в 2018 році
- 3 трактором Беларус-1221.2 (рис. 2). Слід зазначити, що, як показали результати тензометрування, запас потужності при застосуванні трактора ХТЗ-242К був досить значним, що дозволило без обмежень проводити сівбу на швидкості до 12 км/год.

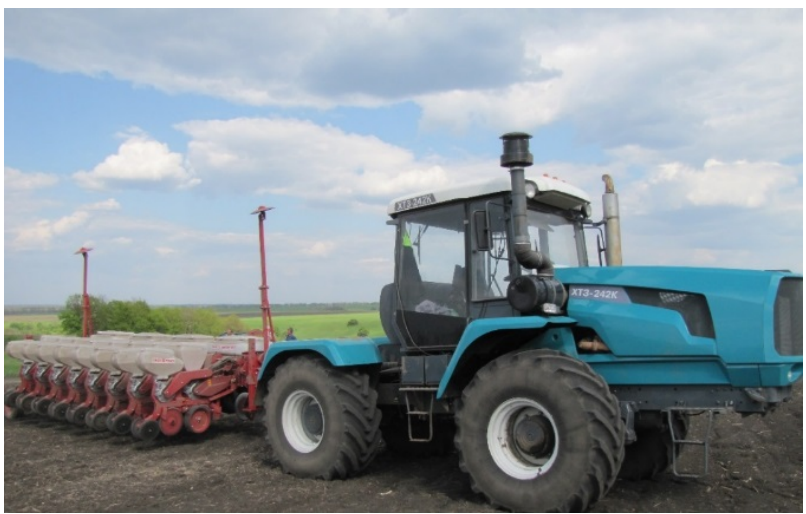

Рис. 1. Агргегат для сумісних посівів кукурудзи та сої в складі трактора ХТЗ-242К та дослідного зразка спеціалізованої сівалки на базі «Vega-8 Profi»

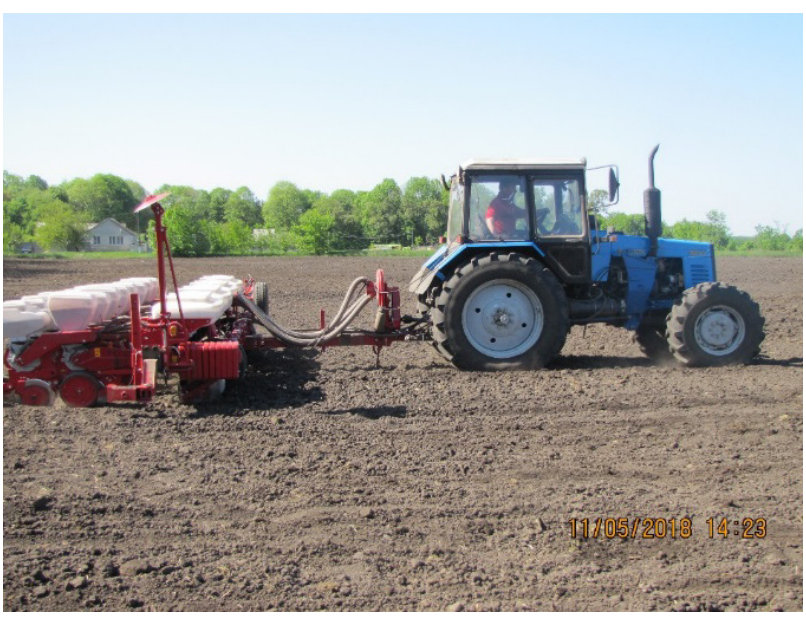

Рис. 2. Агрегат для сумісних посівів кукурудзи та сої в складі трактора «Беларусь 1221.2.» та сівалки на базі «Vega-8 Profi»

Як при дослідженнях в 2017 році, так і в 2018 році передпосівний обробіток проводився культиватором КПС-4. Стан поля, а також показники якості передпосівного обробітку наведені в табл. 3.

Аналіз даних таблиці показує, що вологість та твердість ґрунту в період проведення передпосівного обробітку як в 2017, так і в 2018 роках були практично однаковими.

Якість передпосівного обробітку характеризувалась глибиною обробітку. Незважаючи на те, що середня глибина, яка становила 7,0..6,3см, 
була близькою до оптимальної, рівномірність глибини була незадовільною, про що свідчить значна різниця між мінімальною та максимальною глибиною: від 2,0 до 15,0 см. Наявність такої нерівномір- ності по глибині обробітку могла в подальшому вплинути на польову схожість насіння сумісних культур. Як результат, густота рослин в період повних сходів складала для кукурудзи 3,77 шт/п.м.

Таблиця 2. Характеристики насіння культур, що висівалось при сумісних посівах сівалкою «Vega-8 Profi»

\begin{tabular}{|c|c|c|c|c|c|}
\hline \multirow{3}{*}{ Найменування показників } & \multicolumn{5}{|c|}{ Значення показників в заліжності від культур, які висівали } \\
\hline & \multicolumn{3}{|c|}{2017 рік } & \multicolumn{2}{|c|}{2018 рік } \\
\hline & кукурудза & $\operatorname{cog}$ & сорго & кукурудза & соя \\
\hline сорт культур, що висівались & $\begin{array}{c}\text { Соломенська } \\
298 c p \\
\end{array}$ & Хуторяночка & Самурай & Любава & Хуторяночка \\
\hline маса 1000 насінин, г & 367,0 & 181,7 & $30-35$ & 200,0 & 100,0 \\
\hline лабораторна схожість, \% & 98,0 & 94,0 & 98 & 88,0 & 89,0 \\
\hline $\begin{array}{l}\text { рекомендована норма висіву: } \\
\text { на } 1 \text { п.м. } \\
\text { тис.шт/га }\end{array}$ & $\begin{array}{c}6 \ldots 7 \\
85,7 \ldots 1000,0\end{array}$ & $\begin{array}{c}18,0 \\
2571,4\end{array}$ & $\begin{array}{c}6 \ldots 7 \\
85,7 \ldots 1000,0\end{array}$ & $\begin{array}{c}6 \ldots 7 \\
85,7 \ldots 1000,0\end{array}$ & $\begin{array}{c}18,0 \\
2571,4\end{array}$ \\
\hline
\end{tabular}

Таблиця 3. Показники стану поля та якості передпосівного обробітку при дослідженнях роботи сівалки

\begin{tabular}{|c|c|c|c|c|}
\hline \multirow{2}{*}{\multicolumn{2}{|c|}{$\begin{array}{c}\text { Найменування } \\
\text { показників }\end{array}$}} & \multirow{3}{*}{$\begin{array}{c}\text { Одиниці } \\
\text { вимірів } \\
\%\end{array}$} & \multicolumn{2}{|c|}{ Значення показників } \\
\hline & & & 2017 рік & 2018 рік \\
\hline Вологість ґрунту в шарах: & $\begin{array}{c}0 . .5 \mathrm{~cm} \\
5 \ldots 10 \mathrm{~cm} \\
10 \ldots 15 \mathrm{~cm}\end{array}$ & & $\begin{array}{l}21,0 \\
26,2 \\
28,0 \\
\end{array}$ & $\begin{array}{l}22,9 \\
25,9 \\
26,7\end{array}$ \\
\hline Твердість ґрунту в шару: & $\begin{array}{c}0 . .5 \mathrm{~cm} \\
5 \ldots 10 \mathrm{~cm} \\
10 \ldots 15 \mathrm{~cm} \\
\end{array}$ & мПа & $\begin{array}{l}1,1 \\
1,4 \\
1,7 \\
\end{array}$ & $\begin{array}{c}0,95 \\
1,06 \\
1,4 \\
\end{array}$ \\
\hline Глибина обробітку: & $\begin{array}{c}\text { середня } \\
\text { мінімальна } \\
\text { максимальна }\end{array}$ & $\mathrm{CM}$ & $\begin{array}{c}7,0 \\
2,0 \\
15,0\end{array}$ & $\begin{array}{c}6,3 \\
4,0 \\
14,0\end{array}$ \\
\hline
\end{tabular}

Слід зазначити, що передпосівний обробіток, який проводився як в 2017, так і в 2018 році агрегатами в складі трактора Т-150К та культиватора КПС-4, на жаль, не забезпечив необхідної якості, особливо стосовно рівномірності глибини обробітку.
Основні показники якості роботи дослідного зразка сівалки на базі «Vega-8 Profi», які визначали при дослідженнях 2017-го та 2018-го років, представлені в табл. 4.

Таблиця 4. Основні показники якості виконання сумісних посівів дослідної сівалки «Vega-8 Profi»

\begin{tabular}{|c|c|c|c|c|c|}
\hline \multirow{3}{*}{\multicolumn{2}{|c|}{$\begin{array}{c}\text { Найменування } \\
\text { показників }\end{array}$}} & \multirow{4}{*}{$\begin{array}{c}\text { Одиниці } \\
\text { вимірів } \\
\text { шт/п.м. }\end{array}$} & \multicolumn{3}{|c|}{ Значення показників } \\
\hline & & & \multirow{2}{*}{$\begin{array}{c}2017 \text { рік } \\
\text { Сумісні } \\
\text { посіви }\end{array}$} & \multicolumn{2}{|c|}{2018 рік } \\
\hline & & & & Сумісні & Одиночні \\
\hline встановлена норма висіву & $\begin{array}{c}\text { кукурудза } \\
\text { соя }\end{array}$ & & $\begin{array}{c}6,4 \\
14,0 \\
\end{array}$ & $\begin{array}{l}10,5 \\
18,0 \\
\end{array}$ & $\begin{array}{l}10,5 \\
18,0\end{array}$ \\
\hline робоча швидкість & & км/год & 12,0 & $8,5-9,5$ & $8,5-9,5$ \\
\hline глибина загортання насіння & $\begin{array}{l}\text { кукурудза } \\
\text { сої }\end{array}$ & $\mathrm{CM}$ & $\begin{array}{c}8,1 \\
6,45\end{array}$ & $\begin{array}{l}6,5 \\
6,6\end{array}$ & $\begin{array}{l}5,8 \\
6,6\end{array}$ \\
\hline густота посіву в період повних сходів & $\begin{array}{c}\text { кукурудзи } \\
\text { сої }\end{array}$ & шт/п.м & $\begin{array}{l}3,77 \\
6,49\end{array}$ & $\begin{array}{c}4,2 \\
14,8 \\
\end{array}$ & $\begin{array}{c}8,2 \\
15,0\end{array}$ \\
\hline польова схожість & $\begin{array}{c}\text { кукурудзи } \\
\text { сої }\end{array}$ & $\%$ & $\begin{array}{l}62,8 \\
40,0\end{array}$ & $\begin{array}{l}40,0 \\
80,0\end{array}$ & $\begin{array}{l}75,0 \\
82,0\end{array}$ \\
\hline $\begin{array}{l}\text { розподіл рослин вздовж рядка: } \\
\text { середня відстань між рослинами }\end{array}$ & $\begin{array}{l}\text { кукурудза } \\
\text { соя }\end{array}$ & $\mathrm{CM}$ & $\begin{array}{l}29,2 \\
11,9\end{array}$ & $\begin{array}{c}24,5 \\
7,0-7,44\end{array}$ & $\begin{array}{l}13,3 \\
7,75\end{array}$ \\
\hline коефріцієнт варіації & $\begin{array}{c}\text { кукурудза } \\
\text { соя }\end{array}$ & & $\begin{array}{l}75,0 \\
89,4\end{array}$ & $\begin{array}{l}77,0 \\
91,4\end{array}$ & $\begin{array}{l}58,6 \\
55,3\end{array}$ \\
\hline
\end{tabular}

Інженерія природокористування, 2019, №3(13), с. 35 - 42 Engineering of nature management, 2019, \#3(13), p. 35 - 42 
Аналіз даних таблиці показує наступне. Глибина висіву насіння як кукурудзи, так і сої змынювалася від 8,1 до 5,8 см, що дещо быльша оптимальної величини 4-5 см. Слід вважати, що однією з причин цього був неякісний по рівномірності глибини передпосівний обробіток.

Дані таблиці по густоті посіву показують, що при встановленій нормі висіву в 2017 році насінин кукурудзи - 6,4 шт/п.м. та 14 шт/п.м. насінин сої в період повних сходів одержано сходів кукурудзи 3,77 шт/п.м. та 6,5 шт/п.м. сходів сої, а в 2018 при встановленій нормі висіву кукурудзи 10,5 шт/п.м. та 18 шт/п.м. сої, одержано по 4,2 шт/ п.м. сходи кукурудзи та 14,8 шт/ п.м. сходів сої. Для виявлення головної причини цього явища було висунуте припущення, що не забезпечується встановлена норма висіву, тобто висівається менша кількість насіння, і однією з причин цього є недостатній рівень вакууму у висівних апаратах.

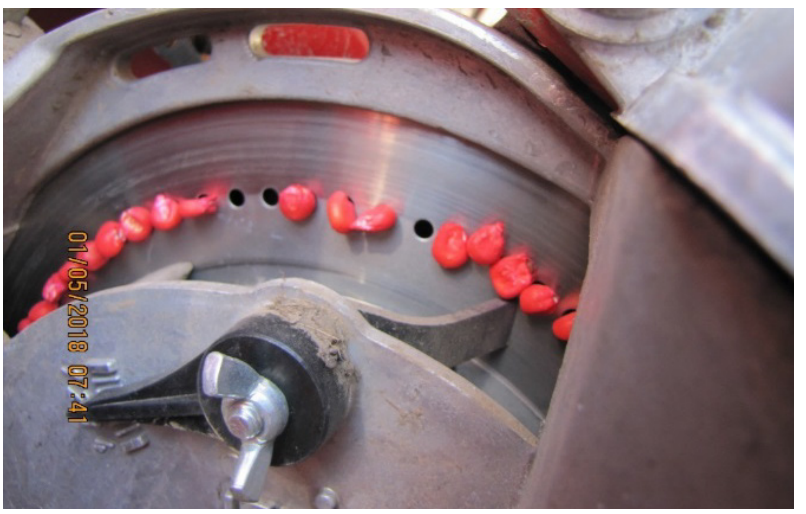

Рис. 3. Незаповненість насінням кукурудзи отворів висівного диска.

Особливо це стосувалось кукурудзи, насіння якої має складну геометричну форму. 3 цією метою в дослідженнях 2018 року були здійснені так звані «одиночні» посіви, при яких в одному випадку висівалась тільки кукурудза, а привід на висівний апарат висіву сої відключався і перекривався вакуум на ці висівні апарати, в другому випадку навпаки - весь вакуум направлявся в висівний апарат для висіву сої. Як показує аналіз даних по одиночних посівах, кількість сходів кукурудзи збільшилась майже в два рази: з 4,2 шт/п.м. до 8,2 шт/п.м. При цьому збільшилась рівномірність розподілу рослин: коефіцієнт варіації змінювався від 77,0\% до 58,65\%.

Ці дані підтверджують припущення, що при сумісних посівах висівалось менша кількість насіння кукурудзи в порівнянні з встановленою нормою висіву. Підтвердженням цього $€$ наявність пропусків насіння на висівному дискові кукурудзи (рис. 3), а також дані автоматичної системи контролю висіву, які фріксували до $20 \%$ пропусків в висівних апаратах кукурудзи (рис. 4).

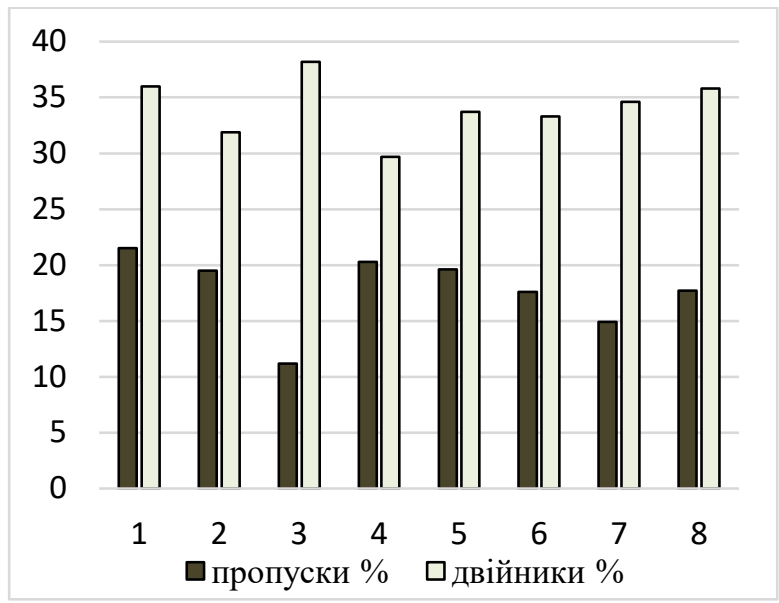

Рис. 4. Пропуски та двійники насіння кукурудзи при сумісних посівах на полі № 1 дослідною сівалкою на базі «Vega-8 Profi»

Таблиця 5. Вплив швидкості сівби дослідної сівалки на базі «Vega-8 Profi» на густоту насадження та польову схожість насіння

\begin{tabular}{|c|c|c|c|c|}
\hline \multirow{2}{*}{$\begin{array}{c}\text { Найменування } \\
\text { показників }\end{array}$} & \multirow{2}{*}{$\begin{array}{c}\text { Одиниця } \\
\text { вимірів }\end{array}$} & \multicolumn{3}{|c|}{ Значення показників } \\
\cline { 3 - 5 } & & 10 км/год & 7,7 км/год & 4,7 км/год \\
\cline { 3 - 5 } & шт/п.м & 2,8 & 2,6 & 2,7 \\
\hline Густота посівів кукурудзи & тис. шт/м & 40,0 & 37,6 & 38,6 \\
\hline Густота посівів сої & шт/п.м & 6,4 & 5,5 & 78,5 \\
& тис. шт/м & 87,14 & & 78,4 \\
\hline Польова схожість: & \multirow{2}{*}{$\%$} & 46,7 & 43,3 & 45,0 \\
кукурудзи & & 33,9 & 30,6 & 30,5 \\
сої & & & & \\
\hline
\end{tabular}

Під час досліджень 2017 року визначався вплив зміни швидкості сівби на норму висіву. За критерій оцінки якості приймався кінцевий результат сівби - польова схожість. Як показував аналіз результатів досліджень (табл. 5), при зміні швидкості руху сівалки в межах від 4,70 до 10,0 
км/год, а відповідно польова схожість і норма висіву, практично не змінювались, що підтверджує спроможність дослідної сівалки в цьому діапазоні швидкостей забезпечувати стабільність висіву.

Відповідно до програми та методики досліджень роботи сівалки визначався кінцевий результат і вплив сумісної сівби на врожайність силосної маси (табл. 6). Досить високою виявилася біологічна врожайність кукурудзи на «одиночних» посівах, де густота посівів була майже вдвічі більшою, ніж на сумісних посівах, що $€$ ще одним підтвердженням про основну причину недостатньої густоти сходів кукурудзи на сумісних посівах.

Таблиця 6. Біологічна врожайність силосної маси при сумісних посівах дослідною сівалкою «Vega-8 Profi»

\begin{tabular}{|c|c|c|c|c|c|}
\hline \multirow{3}{*}{ Найменування показників } & \multicolumn{5}{|c|}{ Значення показників } \\
\hline & \multicolumn{2}{|c|}{2017 p. } & \multicolumn{3}{|c|}{2018 p. } \\
\hline & $\begin{array}{l}\text { Сумісні } \\
\text { посіви }\end{array}$ & $\begin{array}{l}\text { Конт- } \\
\text { роль }\end{array}$ & $\begin{array}{l}\text { Сумісні } \\
\text { посіви }\end{array}$ & $\begin{array}{c}\text { Одиночн } \\
\text { посіви }\end{array}$ & $\begin{array}{l}\text { Конт- } \\
\text { роль }\end{array}$ \\
\hline $\begin{array}{c}\text { врожайність силосної маси: т/га } \\
\text { кукурудзи та сої; } \\
\text { сорго та сої; } \\
\text { тільки кукурудзи } \\
\text { тільки сої; } \\
\text { тільки сорго } \\
\end{array}$ & $\begin{array}{c}15,34 \\
8,68 \\
12,99 \\
2,33 \\
6,35 \\
\end{array}$ & $\begin{array}{c}- \\
- \\
91,6 \\
- \\
-\end{array}$ & 56,8 & $\begin{array}{l}59,6 \\
25,0\end{array}$ & 45,0 \\
\hline $\begin{array}{ll}\text { густота стояння перед збиранням } \\
\text { тис. шт/га: } & \text { кукурудзи } \\
& \text { сої } \\
& \text { сорго } \\
\end{array}$ & $\begin{array}{l}56,0 \\
81,8 \\
32,9\end{array}$ & $\begin{array}{c}80,0 \\
- \\
-\end{array}$ & $\begin{array}{c}69,9 \\
70,0 \\
-\end{array}$ & $\begin{array}{c}94,3 \\
- \\
\end{array}$ & $\begin{array}{c}109,9 \\
- \\
\end{array}$ \\
\hline
\end{tabular}

Як свідчить аналіз даних таблиці, врожайність силосної маси в 2017 році була значно меншою, ніж у 2018 році. Основною причиною була значна посуха в період вирощування. Але незважаючи на це, як загальна врожайність сумісних посівів, так і окремо врожайність тільки кукурудзи була вищою, ніж на контролі на 30 \%. При дослідженнях 2018 року на полі, яке було достатньо забезпечене добривами біологічна врожайність силосної маси сумісних посівів суттєво вища (56,8 т/га) в порівнянні 3 контролем (45,6 т/га).

Відповідно до програми досліджень, у 2018 році вивчався вплив силосної маси сумісних посівів на продуктивність корів. Методом господарського обліку визначались надої молока та його якість за умови, що в раціоні корів був силос сумісних посівів кукурудзи та сої, а також приріст ваги при відгодівлі телиць силосом з сумісних посівів (рис. 5). За даними керівництва дослідного господарства річний надій на корову в 2018 році, за порівнянням з 2017 роком за рахунок застосування кукурузо-соєвого силосу замість звичайного кукурудзяного, виріс з п'яти тисяч восьмисот вісімдесяти до шести тисяч ста двадцяти п'яти кілограмів, тобто на двісті сорок п'ять кілограмів на одну корову.

3 урахуванням того, що в господарстві $€$ понад шістсот корів, за рік надбавка молока склала сто сорок сім тонн.

При цьому покращилась якість молока, так:
- жирність зросла з трьох цілих двадцяти однієї сотої відсотка до трьох цілих сорока трьох сотих відсотків,

- а білковість з трьох цілих дев'яти сотих відсотка зросла до трьох цілих тридцяти шести сотих відсотків.

При відгодівлі телиць старше шести місяців середньодобовий приріст маси збільшився з семисот грам до семисот вісімдесяти дев'яти грам, тобто на дванадцять і шість десятих відсотків.

\section{Висновки}

1. Дослідний зразок спеціалізованої сівалки для сумісних посівів зернових і бобових культур на базі «Vega-8 Profi» забезпечує стабільний висів двох сумісних культур в один рядок в діапазоні швидкостей від 4,7 до 12 км/год.

2. Виходячи із експериментів, сівалка задовільно агрегатується з тракторами різної потужності (ХТЗ-242К, Беларус 1221.2).

3. Сівалка забезпечує задовільну якість сумісної сівби насіння кукурудзи, сорго та сої.

4. Якість силосної маси сумісних посівів кукурудзи та сої забезпечує підвищення удоїв та жирності молока, а також приріст маси при відгодівлі телиць силосом з кукурудзи і сої.

5. Виявлені при дослідженнях недоліки в роботі дослідного зразка спеціалізованої сівалки для сумісних посівів $€$ основою для подальшого удосконалення сівалки. 


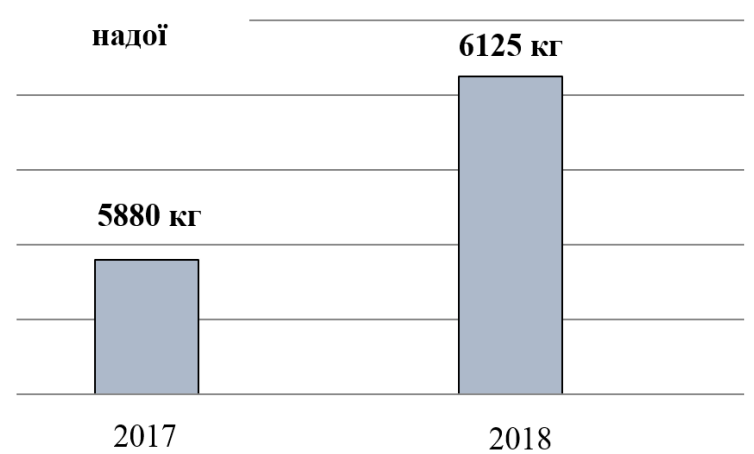

+245 кг на корову +147 тонн по господарству

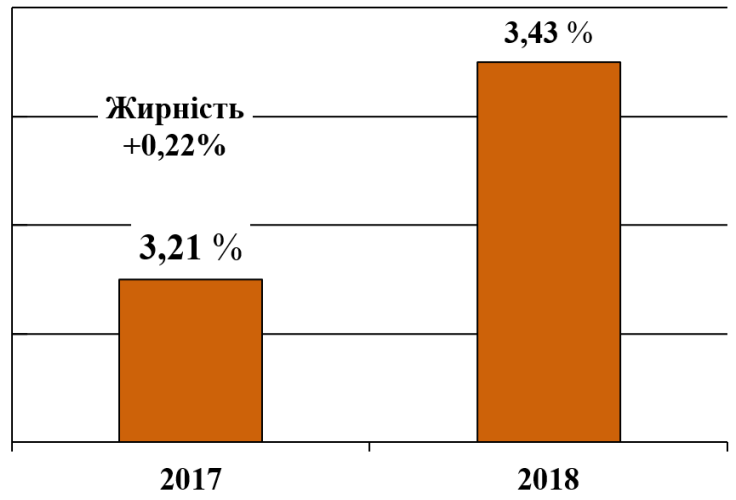

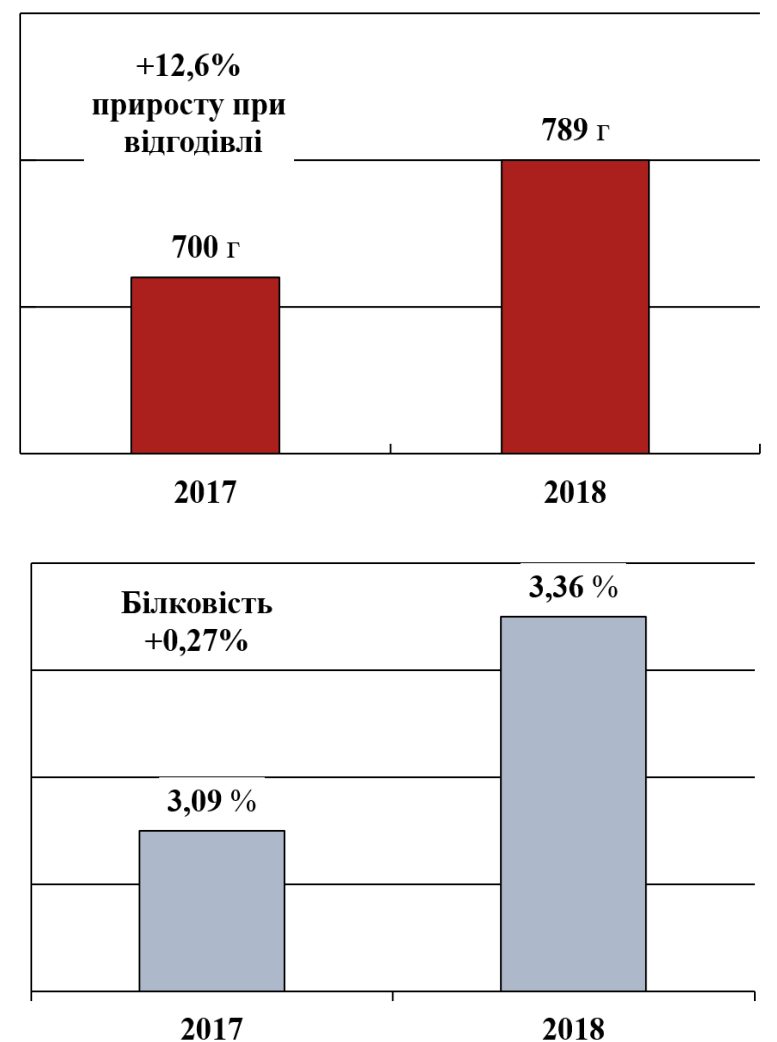

Рис. 5. Показники надоїв та якості молока за 2018 рік в порівнянні з 2017 роком та приріст живої маси телиць.

\section{Література}

1. Кузьменко О.С. Проміжні та сумісні посіви в Україні. / О.С. Кузьменко. - Київ: Вища школа. $1986-175$ c.

2. Нові можливості при сумісних посівах кормових культур. / В.І. Мельник, В.І. Пастухов, М.О. Циганенко та інші. // Інженерія природокористування. - 2018. №2. - с.32-36.

3. Ямкова В. Вирощування сумісних посівів кукурудзи та сої. http:/propozitsiya.com/ua/ virosh/chuvanga-sumichich-posiviv-kukurudzitasoyi.

4. Бегей С.В. Проміжні та сумісні посіви / С.В. Бегей. - К. Урожай, 1980 - 57 с.

5. Будницький, О.С. Кузьменко, П.І. Кухарчук. Вирощування кукурудзи в суміші з соєю та соняшником на силос / О.Г. Будницький, О.С. Кузьменко, П.І. Кухарчук. - Урожай, 1970 - 16 с.

6. Каплуновський П.С. Досвід вирощування кукурудзи в суміші з соєю та буркуном білим в посушливій степовій зоні / П.С. Каплуновський. Держсільгоспвидав УРСР, 1963 - 224 с.

7. Семенов А.М. Урожайність та кормові якості зеленої маси кукурудзи та сої у сумісних посівах / А.М. Семенов. Вісник науки, 1969, №3 - с. 46-42.

\section{References}

1. Kuzmenko O. Intermediate and compatible crops in Ukraine. / Kuzmenko O.S. - Kyiv: Higher school. 1986. $-175 \mathrm{p}$.

2. New possibilities for joint crops of forage crops. / V. Melnik, V. Pastukhov, M. Tsiganenko and others. // Engineering of nature use. - 2018. №2. - p.32-36.

3. Yamkova V. Growing of compatible crops of corn and soya. http: /propozitsiya.com/u/virosh /chuvanga-sumichich-posiviv-kukurudzitasoyi.

4. Begey S.V. Intermediate and compatible crops / S. Beegey. - K. Harvest, 1980. - 57 p.

5. O. Budnitsky, O. Kuzmenko, P. Scullion. Growing corn in a mixture with soybean and sunflower on silage / O. Budnitsky, O. Kuzmenko, P. Scullion. - Vintage, $1970-16 \mathrm{p}$.

6. Kaplunovsky P. The experience of growing corn in a mixture with soy and bitter white in the dry steppe zone / P. Kaplunovsky - State Agriculture Ministry of the USSR, 1963. - $224 \mathrm{pp}$.

7. Semenov AM Crop yield and feed quality of green maize and soybean in compatible crops / A.M. Semenov Journal of Science, 1969, No. 3. - p. 46-42. 


\title{
Результаты исследований работы опытного образца специализированной сеялки для совместных посевов кормовых культур
}

\author{
В.И. Мельник, В.И. Пастухов, Н.В. Бакум, М.А. Циганенко, \\ А.А. Романашенко, В.В. Качанов, Д.В. Крохмаль
}

В статье приведены результаты исследований в 2017 и 2018 годах работы опытного образца специальной сеялки на базе «Vega-8 Profi» для совместных посевов зерновых и бобовых кормовых культур. Исследования проводились в производственных условиях двух опытных хозяйств - института Северо-Востока национальной академии аграрных наук Украины в Харьковской (2017) и Сумской (2018) областях.

При исследованиях, которые проводились в соответствии с разработанной программой и методики, определялись показатели качества работы сеялки, влияние совместного посева кукурузы и сои на урожайность силосной массы, а также влияние полученной силосной массы на продуктивность коров.

Ценность совместных посевов заключается в эффективном использовании земельных площадей, а также более качественному составу кормов. Наиболее эффеккивные совместные посевы кормовых культур с бобовыми, которые не только обогащают почву азотом, который образуется на корнях бобовых, а и увеличивают количество белка и протеина в кормовой единицы.

Кроме определения преимуществ и положительных сторон в работе опытного образца сеялки, фиксировались отказы и недостатки в работе сеялки, которые стали основанием для дальнейшего усовершенствования ее конструкции.

Обобщая результаты двухлетних исследований работы сеялки показали, что совместные посевы кукурузы и сои обеспечивают урожайность силосной массы на $30 \%$ выше, чем при посевах только кукурузы. В соответствии с программой исследований, в 2018 году изучалось влияние силосной массы совместных посевов на продуктивность коров. Методом хозяйственного учета определялись надои молока и его качество при условии, что в рационе коров был силос совместных посевов кукурузы и сои, а также прирост веса при откорме телок силосом с совместимых посевов.

Кормление коров полученным силосом обеспечила повышение удоя и жирности молока и прирост веса при откорме телок по сравнению с силосом только кукурузы.

Ключевые слова: опытный образец, сеялка, совместимые посевы, кормовые культуры, качество сева, биологическая урожайность, силосная масса, эфффективность кормов, продуктивность коров.

\section{Abstract}

\section{The results of research work of a prototype of a specialized seed drill for joint crops of forage crops}

V.I. Melnik, V.I. Pastukhov, M.V. Bakum, M.A. Tsiganenko, A.A. Romanashenko, V.V. Kachanov, D.V. Krokhmal

The article presents the results of research in 2017 and 2018 of the work of a prototype of a special seed drill based on Vega-8 Profi for joint sowing of grain and leguminous forage crops. The studies were carried out under the production conditions of two experimental farms - the Institute of the Northeast of the National Academy of Agrarian Sciences of Ukraine in Kharkiv (2017) and Sumy (2018) regions.

The studies, which were carried out in accordance with the developed program and methodology, determined the quality indicators of the seeder, the effect of joint sowing of corn and soybeans on the yield of silage mass, as well as the effect of the obtained silage mass on the productivity of cows.

The value of joint crops lies in the effective use of land, as well as a better feed composition. The most effective joint crops of forage crops with legumes, which not only enrich the soil with nitrogen, which is formed on the roots of legumes, but also increase the amount of protein and protein in the feed unit.

In addition to determining the advantages and positive aspects in the work of the prototype of the planter, there were recorded failures and shortcomings in the work of the planter, which became the basis for further improvement of its design.

ISSN 2311-1828

http://enm.khntusg.com.ua
Інженерія природокористування, 2019, №3(13), с. 35 - 42

Engineering of nature management, 2019, \#3(13), p. 35 - 42 
Summarizing the results of two-year studies of the work of the planter showed that joint sowing of corn and soybeans provides the yield of silage by $30 \%$ higher than when sowing only corn. In accordance with the research program, in 2018, the effect of silage mass of joint crops on cow productivity was studied. The method of economic accounting was determined milk yield and its quality, provided that in the diet of cows was a silo of joint crops of corn and soybeans, as well as weight gain during fattening of heifers with silage from compatible crops.

Feeding the cows with the obtained silage provided an increase in milk yield and milk fat content and weight gain in fattening heifers compared with only corn silage.

Keywords: experimental model, seed drill, compatible crops, fodder crops, seed quality, biological yield, silage mass, feed efficiency, cow productivity.

\section{Бібліографічне посилання/ Bibliography citation: Harvard}

Melnik, V., Pastukhov, V., Bakum, M., Tsiganenko, M., Romanashenko, A., Kachanov, V. and Krokhmal, D. (2019). The results of research work of a prototype of a specialized seed drill for joint crops of forage crops. Engineering of nature management, 3(13), pp. $35-42$.

Подано до редакції / Received: 05.04.2019 